\title{
EMPOWERMENT IN ISLAMIC SCHOOLS IN YOGYAKARTA AND SYDNEY
}

\author{
Zulkipli Lessy ${ }^{\mathrm{a}}$ \\ Mahmud Arif \\ Sunan Kalijaga State Islamic University Yogyakarta
}

\begin{abstract}
The function of empowerment is to equip people with the knowledge, skills, and perspectives that can sustain and improve both personal and societal well-being. Empowerment can occur by means of education, as well as by supportive programs in social work, community development, and philanthropy. Especially when intended for the poor, marginalized, or minority students, such programs should be well-focused on methods for building long-term capabilities and for strengthening societal participation. Our investigation documented empowerment methods and effects in three Islamic-based, partially statefunded, co-educational schools, one located in Yogyarkarta, Indonesia, and two located in Sydney, Australia. The study gathered individual and group accounts from teachers, academic staff, and parents at these schools. Their accounts were examined with reference to the educational precepts valued by the schools and their communities. This qualitative case-study used interviews, focus group discussions, and review of selected documents to examine the significance of education as implemented through curricula that includes moral education. The findings illustrate how such programs serve as empowerment for students toward fulfilling spiritual, economic, and social needs. Islamic moral education was seen to be embedded in many courses, including languages, arts, culture, social studies, sports, and science. This research found that there is an urgency for Islamic schools to grow their resources in order to remain viable, to provide powerless children with access to education, and to empower these students through curricular and extracurricular activities.
\end{abstract}

Keywords: Student empowerment, moral education, Islamic schools, Yogyakarta, Sydney

\section{Introduction}

Studies in Indonesia and Australia have examined empowerment gained through education provided to children in poor families, minority groups, and marginalized communities (Hatton, Munns, \& Dent, 1996; Kindervatter, 1979; Nilan, 2009; Prasilowati, 2000; Zulfikar, 2009). These children have needed opportunities for better-quality education, even in wealthy countries and certainly in less developed and underdeveloped nations. Studies have focused also on education for children from immigrant or indigent families. And several studies have observed church-run schools and community education programs in poor urban neighborhoods of developed countries, including programs in the USA (Cipolle, 2010; Ferguson, 2008; Nieto, 2008).

Our research in Yogyakarta examined a school initiated by the religious community to provide free education for children of indigent families. This community was already engaged in periodic philanthropic giving for the poor. Now, for over a decade, it has initiated and sustained free elementary schools in provinces on the Island of Java, which include Yogyakarta, Central Java, West Java, and Jakarta. It is beneficial that the Indonesian Ministry of Education and the Ministry of Religious Affairs are funding an elementary school system throughout these provinces. Nonetheless, this public education is not completely free of costs for the students' families. Parents must pay for their

a Correspondence can be directed to: zulkifid@yahoo.com 
children's school uniforms, textbooks, and extracurricular activities. To remedy this gap, the Sekolah Dasar (SD) Juara school of Yogyakarta is funding these ancillary aspects so that there is no cost to students of indigent families. The schooling thereby assists educational empowerment for children whose families could not afford the fees. In addition, the school and surrounding community believe that the inclusion of Islamic moral education in school programs is valuable in preparation for a more secure future. Indeed, a variety of schools in many countries have historically been founded in order to include such components in curricula (Bennets \& Bone, 2019; Cheung, 2008; Chowdhury, 2016; Lam, 1991; Lukens-Bull, 2000; Osman, 2019).

Our research also included two affordable Islamic schools in Sydney, Australia. In these settings, we gained a comparative study of the empowerment in Yogyakarta for indigent children and the empowerment in Sydney for children in a minority cultural group, namely Muslims living in a Christian-majority society. The two Australian schools have only Muslim enrollment and the curricula for both of these schools include Islamic teachings, which necessitates differences from the public school content. Parents and faculty see this moral education as essential for empowering students. By contrast with SD Juara in Yogyakarta, the Islamic schools in Sydney function in an environment with ubiquitous societal contrasts, which affect the differential distribution of benefits and the patterns of relationships within society.

Societal inequities can be individually or structurally based (Foster, 1981), and in Australia they are connected not only to locale, social environment, ethnicity, and religious background, but also to migration patterns and minority nationality groups. In terms of religious inequality, for example, research has found that Australian Catholic children lack full access to educational opportunities due to shortages of accommodations, staff, and facilities (Trethewey, 1990). According to Maslen (1992), Catholic education historically was locked into long-standing hindrances such as traditional routines, problematic school size, and inflexible organization. This led to schools becoming dull workhouses for students and uninteresting stepping-stones to jobs or higher education. In light of such descriptions of minority schooling in Australia, our research examined two Islamic schools in Sydney, relating to how they provide student empowerment amid the effects of being situated in a Christian majority society.

In conducting our study, we looked for furtherance of the empowerment approach toward helping group members to pursue fulfillment of goals and to overcome economic and cultural barriers (Lee, 1996). Educators deal with students who are impeded by scant familial resources, low societal status, notable economic hardship, or pervasive injustice. Payne (2005) maintained that empowerment assists students to attain control of their decisions and actions by minimizing the effects of social and individual factors that impede self-determination. The goal is to expand capacity and self-confidence by relocating power from the environment to the students. Applying the empowerment approach exclusively, however, may be less effective than using it in conjunction with a broader view. Educators can examine the roots of oppression in a society by analyzing history in relation to social policy and inequality. In this approach, students learn how to reduce problems and resolve issues by restructuring false beliefs that had made them feel hopeless (Lee, 1996).

Education is influenced by the disciplines of psychology, sociology, economics, and religious studies. In synthesis, these sources contribute to aspects of empowerment in classrooms. Also, in working with populations who are oppressed, many educators use moral education to encourage students to think analytically and objectively about human issues. As in other religions, Islam includes many theological schools of thought, such as Asy'ariyah, Jabbariyah, and Qadariyah (Goldziher, 1981). The latter says that since humans are incapable of challenging divine power, any persons born into poverty can only see it as a fate they must accept. But in the more recent context of moral education, educators do not adopt a fatalistic perspective, but instead strive to have students learn to empower themselves and to progress toward personal liberation and away from negative cultural and societal factors and from fatalistic perspectives (Lee, 1996). 


\section{Empowerment in the Context of Islamic Moral Education}

Historically and currently, mankind's religions have established schools and universities. Those institutions embed moral values in the academic settings, while simultaneously influencing, and adapting to, cultural and political developments. Reciprocal effects in society generally, and in education specifically, need to be understood in the context of the underlying beliefs. Morality, as a component of course content in such schools, and particularly for this study in contemporary Islamic schools, contributes to societal functioning. The Islamic principle âdab, meaning good behavior and the principles of hospitality, etiquette, politeness, civility, and culture, is a valued component in such curricula (Al-Syaukâni, 1417; Halstead, 2007). The Arabic verb addaba, meaning to guide and shape behavior and character, has a central function in Islamic education. These linguistic markers emphasize Islamic moral education as a means by which students attain physical, psychological, social, scientific, and technological abilities. Moral education arouses the minds and hearts of students as they learn independence, responsibility for actions, and the life skills for fulfilling their spiritual, social, economic, and cultural needs. Such lessons are part of comprehensively planned Islamic curricula for empowerment (Hussain, 2008).

Two notable values in Islamic education are developing students' understanding of social ethics and promoting students' respect for adherents of other religions in order to allow harmony among varied communities (Cardinal, 2006). Education, as based in Islam, is a process to equip students with knowledge and skills (Hills, 1985) so that students are empowered to confidently take part in discussions and debates, to conduct research, and to remain open to correction and revision (Panjawi, 2012). Islamic education is expected to encourage motivation for research, so that student awareness of physical and social phenomena, as well as of divinity, will expand and persist. Thereby they gain respect for themselves as potential producers of knowledge, based on scientific methods and on the appreciation of Giver of knowledge (Allah), and they strengthen their openness to correction and revision (Panjawi, 2012).

Heydon (1997) observes that citizens expect schools and colleges to teach moral values in order to reduce bullying and cyclic conflict since moral education guides students to set better examples for others. Indonesian educational policy implements forms of moral education in the national curriculum as one way to reduce violence. Heydon (1997) asserts that people who act according to moral rules will not do violence, that students who are morally educated will not apply an attitude of conflict, and that educators can serve as anti-violence models for students. Moral education functions longterm to arouse awareness of students from varied backgrounds to improve their quality of life and to diminish any cycles of violence or poverty in their families. Islamic education therefore requires moral principles to be modeled by educators, administrative staff, and other school personnel. It is crucial for students at young ages to learn that community members should differentiate between good and bad, and to learn what behavior can be accepted and what should be rejected. Exemplary education thereby creates beneficial change in local communities and in society overall (Alavi, 2008)

Twin questions, therefore, were pursued in our research. How is Islamic moral education significant in contemporary life? And how do contemporary Islamic schools empower students to participate as independent, effective, and responsible learners?

\section{Method}

This research used personal inquiry to explore philosophy supporting curricula, nature of subjects taught, methods of teachers, connections among topics, options for extracurricular activities, and daily treatment of students. Participants were asked a series of questions relevant to the study topics and were given the opportunity to elaborate on their answers. This qualitative approach included observation of participants in the school settings and personal accounts of their own conversations, social lives, and finances. 
Interviews, observations, and study of documents were conducted at each of three sites: Australian Islamic College of Sydney, Al-Noori Muslim School, New South Wales (NSW), Australia, and Sekolah Dasar (SD) Juara, Yogyakarta. These three are Islamic, but also public, schools. They are open to anyone seeking to enroll. The three schools were chosen on the basis of being Islamic schools providing at least 70 percent of the coursework to fulfill government requirements because they receive up to 30 percent of their total budget for teaching expenditure from the state. The schools' mottos are also in line with objectives of this research, namely to achieve the highest finest attitude (akhlâq al-karimah) according to Islamic teachings in the Qur'an and hadith.

Participants were school headmasters, administrative officials, and parents, selected from the respective communities served by each institution. Each site was initially represented by five persons, so we ended up with fifteen interviewees or respondents. We sought balanced gender representation. Interviews, and in certain cases questionnaires, were used to gather responses regarding attitudes, knowledge, and methods at these independent Islamic schools. Participants were interviewed with the convenience sampling technique to also identify others who could qualify for inclusion. Interviews were done primarily in focus group discussions (FGD) in Yogyakarta and Sydney, but some interviews were conducted through email.

\section{Data Collection and Analysis}

The researchers used open-ended questions to elicit participants' knowledge, perceptions, experience, and feelings about the schools. There was a flexible questionnaire that guided interviewers to obtain clarification as needed and to formulate extended questions for more detailed descriptions from participants during the conversations, interviews, and focus group discussions, all of which were conducted in person on school grounds.

Data analysis examined relevant documents, fact findings, and policy-case analysis, and used online databases, references, and sources prescribed in printed and non-printed materials. Creswell (2013) suggests specific methods for such qualitative analysis, including the illustrative method and the analytic comparison alternative. The illustrative method, which uses empirical evidence to illuminate theory, was employed by this researcher by means of observing settings, interviewing subjects, and studying documents related to educational empowerment in Yogyakarta and Sydney. Analytic comparison sought similarities and contrasts. Domain analysis was applied to cultural settings. Neuman (1997) defined domains as themes resulting from interpreting "a cultural scene or social setting", with the ideal type applied as "mental abstractions of social relations or processes" (p. 429). Neuman has summarized that the researcher in context should draw conclusions after identifying both the ideal and the reality. Accordingly, educational empowerment ideas were compared to realities encountered in the field.

\section{Results}

\section{Summary of Participant 1: Sekolah Dasar (SD) Juara}

Sekolah Dasar (SD) Juara is the first charitable independent elementary school established in Yogyakarta. It started in 2007 with 39 students and now has almost 300 . The school's vision is to mold a self-sufficient generation of Indonesian children, as they are lifted out of poverty by its specific mission of providing free and good quality education for the poor. SD Juara educates children, ages 6 to 12, from indigent families. Selection criteria prioritize children with parents who are very poor, lack a permanent job, and wish to obey the teachings of Islam. Students are provided with free tuition, school uniforms, field trips, and participation in recreational and extra-curricular activities. SD Juara exempts enrollees from all fees all the way through graduation.

SD Juara is neither a madrasah (mosque school) nor an Islamic pesantren (boarding school). It is a co-educational school that educates its students to the level needed to qualify for acceptance 
into junior high school. Its courses provide Islamic religious teachings and moral education, but also the full Indonesian national curriculum of Arabic language, mathematics, science, arts, and sports (Yusuf, 2016). Extra-curricular activities include scouting, swimming, archery, Gamelan (a Javanese musical instrument), and music. SD Juara holds morning habituation in its mosque with reading 99 Asmâul Husnâ (good names of Allah) and a dhuha (morning) prayer. This school has notable academic achievements, including the success of one of its students in reaching the second round of the competitive Science Olympiad of Kuark. SD Juara also seeks to educate students of multiple intelligences, to develop all potential abilities, and to equip students with life skills and with the ability to succeed at further levels of education (Interview). SD Juara is an innovative standout among schools and is facilitating the poor, indigent, marginalized, and unfortunate children to have equal opportunities in education.

\section{Summary of Participant 2: Australian Islamic College of Sydney (AICS)}

The Australian Islamic College of Sydney (AICS) is a co-educational school, with levels from Kindergarten to Year 12, providing education underpinned by religious values. It operates within the policies of the New South Wales Board of Studies and seeks enrollees supportive of its philosophy and ethos. Similar to SD Juara, AICS is not a traditional madrasah but rather is a modern school, and it participates in Australia's system of partially state-funded education. The school therefore must adopt at least $70 \%$ of the national curriculum, which it then uses in conjuction with Islamic moral education. As a public school, it is open to all, including children of Aboriginal or Torrest Strait Islander origin and children from other minority groups (Australian Islamic College of Sydney, 2017).

AICS aims to offer a holistic education within an Islamic viewpoint. It was founded to serve the Muslim community in Sydney's western suburbs. According to its Principal Dr. Imam Ali, the AICS was initiated by a man who had already built an Islamic school in Perth with a belief that the dakwa (preaching) of Islamic teaching is effective if preached through education. After later migrating to New South Wales, this founder called on the Muslim community there to build AICS (Australian Islamic College of Sydney, 2017). In 1980, Muslim leaders in the suburbs saw a need for a site where their Muslim community could promote and teach Islam. Weekly gatherings were held in homes initially and in the St. Clair community center when attendance increased. The late M.K. Habibullah, a learned community elder, taught the attendees tafsîr (interpretation) of the Qur'an, hadith (sayings of the Prophet Muhammad), and târîkh (Islamic history) to provide them with the understanding of Islamic studies needed for everyday life (Australian Islamic College of Sydney, 2017).

Historically, in 1983 about 100 people founded the Islamic Association of the Western Suburbs of Sydney. The members, with roots from India, Pakistan, Bangladesh, Indonesia, and Fiji, formed a committee to write a constitution for their Association. Two key objectives were to establish a mosque and to open an Islamic school. Their application to the government was at first declined, but in 1986 the city council granted approval, and in March 1986 the association officially registered with the NSW Department of Fair Trading as a charitable organization (Australian Islamic College of Sydney, 2017).

Planning and fundraising led to the purchase of five contiguous lots of land in Mt. Druitt. Included were a cottage and a truck shed. Later the cottage became the Imam's residence, and the truck shed was renovated to become the present mosque. In 1997, modular structures were added and in 2009, a final adjacent block of land was purchased to expand the space for school buildings and for sports facilities such as a rugby court and an indoor gymnasium (FGD; Observation; Australian Islamic College of Sydney, 2017). Temporary structures were gradually replaced with state-of-the-art classrooms, laboratories, and related facilities. Enrollment at AICS has grown to over 1,100 students, and there are more than 100 teaching and non-teaching staff. The school encourages a global outlook, and its stated mission is to nurture skills, talents, and character, enabling students to confidently face a complex future. The school's annual test results in nearly all subjects have steadily risen into the top 40 percent of all NSW schools. These National Assessment Program - Literacy and Numeracy 
(NAPLAN) tests cover reading, persuasive writing, spelling, grammar, punctuation, and numeracy. At the same time, AICS has remained a staunch adherent to core Islamic values and teachings, with a focus on universally accepted morals and behavior (FGD; Australian Islamic College of Sydney, 2017).

\section{Summary of Participant 3: Al-Noori Muslim School (AMS)}

Al-Noori Muslim School (AMS) is a co-educational school for grades Kindergarten to Year 12 and now has a student population of about 1800 (Al-Noori Muslim School, 2017). AMS was founded in 1985 to value excellence in academic achievement, social justice, pastoral care, emotional growth and spiritual development. It is a public school, not a traditional madrasah. Students learn the NSW Education Standards Authority syllabus. Further, they are given instruction to help them be sure of their strengths and to work as independent, confident, and articulate members of the community (Al-Noori Muslim School, 2020). AMS strives to develop the personal and academic potential of each individual, and it emphasizes personal integrity and social responsibility (Al-Noori Muslim School, 2017). The school also fosters partnerships among staff, parents, and the wider community.

AMS achievements include its ranking among the Top 100 schools in New South Wales based on the High School Certificate (HSC) test results in 2016. The school secured this Top 100 standing in its first year of qualifying to participate in the NSW HSC, which is an achievement unique in the history of the ranking system. Also, the AMS' Personal Development, Health and Physical Education (PDHPE) department provides regular opportunities for student competition in sports. In their recent and outstandingly successful year, both the girls' and the boys' teams from AMS were champions in the Bachar Houli Cup. And all students have the opportunity to enjoy a variety of school excursions. (FGD; Al-Noori Muslim School, 2017).

\section{Theme 1: Provision of Education to the Economically Powerless - Sekolah Dasar (SD) Juara}

In a focus group discussion with fifteen parents and three teachers at SD Juara, the topic was how the school empowers students. We asked about partnership among parents, teachers, and students to address difficulties; about encouragement by parents and teachers for children to have high motivation for homework; and about strategies by parents to persuade children to be diligent in preparation for school. We learned that SD Juara is a charitable school accepting Muslim children whose parents and caretakers are poor. Rumah Zakat, a charitable organization, advertises programs through its education division, which funds education for disadvantaged children in undeserved neighborhoods. The programs help these unfortunate children who meet eligibility criteria, based on surveys and home meetings with parents. The school waives tuition and fees, and once a family passes the screening, they can send two children at a time to SD Juara.

The majority of the fifteen parents who attended the meeting stated that they usually partner with their children to help with homework, and if they cannot solve mathemetical problems considered difficult, then they ask a neighbor for assistance. One of the parents interviewees (all of them females), stated that her child often does homework while helping to sell food from their verandah. Earlier each day, the child opens the shop door and arranges chairs for customers before heading for school. Most participants stated that their husbands also help with homeworks whenever feasible.

Parents help teachers at school by sitting beside children who need assistance. The teachers ask parents to check their children's performance at home as well. Parents help to prepare school bags before bedtime, and they check Qur'anic memorization (tahfidz). For some children these two habits are difficult to maintain. Parents at home serve as teachers' partners for study habits, and teachers are parents' partners for building students' values. Participants further told us that teachers act as role models for good character and behavior, such as akhlâq al-karimah (good morality), at school. Students are guided to be eager to share with each other, behave well at home, finish homework, and become independent. 
Included in our research was recent information on the economic conditions of parents of the SD Juara children. For confidentiality, actual names are not used. We identify one student by pseudonym as Banu, a 9-year-old who is now in fourth grade at SD Juara. His father's job as a school security officer pays a low monthly salary. Banu's mother is a homemaker. The couple graduated from secondary school and did not continue their education. The mother said that living as urban migrants in Yogyakarta is hard because prices steadily rise. With only the father's income, the family cannot afford public elementary school, so they accepted being surveyed by SD Juara about their economics and religiosity. The surveyor asked about income, expenses, and how often the family practices prayers. Based on answers and evidence, their child was accepted to enroll in SD Juara. Banu's mother told us that his class begins at 7.00 in the morning, starting with a dhuha (morning prayer) held in the school's mosque and guided by the teacher. The students then go to their classrooms to start lessons. On some days they practice Qur'anic memorization (tahfidz), such as short simple verses in the Amma Chapter. Classes end at 13.00 in the afternoon (Observation \& Interview).

Banu's mother stated that SD Juara conveys lessons suited to the children's capacities and gradually guides students to understand according to each child's physical, affective, and motor growth levels. SD Juara lends course packets on all subjects to students, and when students find a topic difficult, the teachers hold extra classes to help them. This always occurs in fourth to sixth grades prior to the national examination, but it can happen in other grades too. Banu asserted that he is happy that his schooling at SD Juara enables him to practice moral and religious values that he receives in class, to do his five-time daily prayers, to have good will as directed in Islam, such as respect for adults and parents, and to share these benefits with friends.

Other stories came from the father of siblings, pseudonyms Hilal and Halim ( 8 and 10 years old). The boys entered grade 1 after the survey by SD Juara of the economic, spiritual, and social conditions of their family. The father, a high school graduate with a non-permanent job as a construction worker, stated that besides receiving schooling, his children are involved in sports, such as soccer and swimming, and in extra-curricular activities, such as scouting. He mentioned that teachers are friendly and adapt to each child's capacity. Hilal and Halim perform a dhuha prayer in the morning and make a jamâ'ah prayer for dzuhur (mid-day prayer)before noon. On some Fridays, the students do exercises and Qur'anic memorization (tahfídz) from al-Fâtihah to al-Ghâsyiyah Chapters. Students and families attend holy days of Islam, with pengajian (moral congregation), and when teachers, parents, and staff have a school committee meeting, they often invite an ustâdz (Islamic teacher) to give a pengajian.

These detailed case studies of two of the five families expanded our data from parental observation and interviews, as evidence of how charity, benevolence, and philanthropy in Islam are being utilized to give educational access to indigent students and to try to empower them for further success in their future lives (Observation \& Interview).

\section{Theme 2: Empowerment Beginning from Community-Australian Islamic College of Sydney} (AICS)

Australian Islamic College School (AICS) has as its principal Dr. Imam Ali and as its vice principal Ms. Sherin Mohamed, who is responsible for curricula. We interviewed them along with classroom teacher Ms. Tessie Ida James in order to document the school's history, current curricula, and extra-curricular activities. As described earlier, the school began in 1996 by the initiative of an eightmember multicultural School Project Committee representing Pakistan, Fiji, Bangladesh, Indonesia, Turkey, and Egypt, with most members being Muslim. By November the Committee had purchased and installed the structures needed for K-3 classes to start in February 1997, and Grade 4 began in the subsequent term. We learned that the Committee developed syllabi, procured furniture, and recruited students and teachers. Fund-raising events, plus donations from Australia and overseas, enabled the first school building. (FGD; Australian Islamic ollege of Sydney, 2017). The New South Wales State now donates up to 40 percent of the teaching budget. 
For teacher recruitment, Australian Islamic College of Sydney (AICS) prioritizes competence and credentials. Although this is a Muslim school, some teachers and administrative staff are nonMuslim and teach non-Islamic studies (figh and tafsîr). Mr. Ali holds that those who teach these subjects should have a liberal arts diploma and understand Qur'anic and hadith teaching. AICS has embraced multicultural values, and thereby AICS survives in a non-majority Muslim community. Dr. Imam Ali maintained that the school tries to meet the challenge of preserving traditional cultures for people raised in Australia and abroad. Ms. James noted that she and her family, for example, maintain their Indian cultural heritage while residing in Australia.

In regard to empowering students, we learned that AICS selects materials suitable to the students' mental development, using the cognitive approach to education. The school provides the content levels and subject matter required by the state, while adding content-based on local needs, such as Islamic studies, tarîkh (Islamic history), tafsîr (interpretation of the Qur'an) and hadith (sayings of the Prophet Muhammad), and Arabic. Dr. Ali stated that the school could not implement 100 percent of the content required by the state because time is also needed for materials related to cultural backgrounds of the students, families, and community (FGD).

We asked Dr. Ali how the school keeps traditions of students whose parents' backgrounds differ, since they are in a multicultural society where Catholic and Christian values are dominant and the government does not require public schools to teach religion. Dr. Ali stated that the school teaches science, mathematics, languages, physics, and similar courses, plus Islamic studies. The school allocates time for students to practice ibadah (worship), prayers, Qur'anic memorization, and to celebrate the Muslim holy calendar, including Idul Fitr and Idul Adha. The school also focuses on physical education and has a sports center where students can practice activities related to their interests. Rugby or soccer is encouraged for male students, and students can compete in sporting events. Also available are gymnastics, scouting, and the arts, such as singing and nashid (Arabic religious songs) (FGD).

\section{Theme 3: Empowerment through Subsidy for Expanded Curriculum - Al-Noori Muslim School (AMS)}

Al-Noori Muslim School (AMS) had been a public school established in 1985 by Muslims of a nearby community. The school has as its headmaster Mr. Ali Kak. Mr. Ayman Darwich is Deputy Principal of the High School, and Ms. El-Zahab is Deputy Principal of the Junior High School. Similar to AICS, AMS offers preschool, kindergarten, elementary, junior high, and high school levels. Students at AMS have scored well in state examinations and have excelled in intermural sports. After over three decades in operation, Al-Noori Muslim School now boasts alumni employed as teachers, doctors, lawyers, and bankers (FGD).

Our on-site research began as we were guided by the principal and the deputies to observe infrastructure and academic buildings during a half-day tour. We visited classes, laboratories, the music room, playgrounds, administration rooms, teacher rooms, and the gymnastics area. We were introduced in an elementary class, where two teachers were teaching Arabic. Mr. Ali Kak told us that the teachers had established their own Arabic syllabus and course packs because some imported Arabic books from the Middle-East are not suitable to be used for Muslim students in Australia, due to different contexts. For instance, many vocabulary items in imported books are not familiar in the local culture. Instead, the school held a workshop to compose a contextual Arabic reader to respond to students' needs. For this course, the school made its own instructional packets for pre-school to high school levels.

In our conversations and observations at AMS, we heard and saw that the headmaster, teachers, staff, and all others work diligently. They are committed to develop this school by having extra hours of full-day study for students. Students in the state of New South Wales typically attend school from 7:00 in the morning to 15:00 in the afternoon. This school, however, obligates students to spend a longer time in school, so that they can learn subjects that are often difficult, such as mathematics 
and science. Mr. Kah asserted that when competing, one succeeds by spending more time on the same work, as a habit to excel. By having extra school hours, the school can set hard work as the norm for their students, even when other people do not expect it. This resulted in many of their students attaining the highest ranks during the national examinations in 2017. Empowering students is achieved by molding learning habits and making such habits part of the school culture. Twenty years ago this school started with one class. Teachers and staff since then have worked hard to make it become one of the best schools in New South Wales, ranked in the upper 15 percent among all independent schools in the state (FGD).

AMS also teaches psychology by integrating Islamic studies into courses. Islamic studies, tarikh, tafsîr and hadîth, are provided to students in the form of extra classes for perspectives about Islam. When hiring teachers, Mr. Kak pays attention to each candidate's diploma and academic transcript. He interviews and screens teacher candidates himself during their recruitment. The school seeks applicants who are alumni from specialist education backgrounds, not solely from general education or liberal arts. This particular practice has helped AMS maintain its academic standing (FGD).

\section{Discussion}

SD Juara in Yogyakarta and AICS and AMS in Sydney are succeeding in empowering students, providing adequate facilities as needed by their students. AICS and AMS are two of the very few Islamic schools in Sydney, New South Wales, and they have developed successfully in under three decades. They each started from having a single class of no more than 31 students. Their Islamic communities had been seeking to have schools that would become competitive with existing schools, such as the Jewish, Catholic, and public schools in Greater Sydney.

Children at SD Juara are empowered by receiving free education (pendidikan gratis) when they qualify for it based on their parents living below the poverty line according to Indonesia's Board of Statistics or Biro Pusat Statistik. According to Davies (1994), because "education is an enterprise, not a human right" (p. 8), such a situation has worried many parents about their children having fewer opportunities to be educated in competitive public schools due to the barrier of tuition fees. The parents felt they were being blessed because, at SD Juara, their children learn 'secular subjects' at a strong level, while also studying Islamic subjects for empowerment in ethical motivation and life skills. Most parents confirmed that Islamic subjects, including Islamic moral education, are significant for their contemporary life because it guides students' behavior to not only become good and responsible citizens, but also to embrace divinity in life and to become devoted Muslim. In addition to such beliefs, some of the parents were equally concerned about their children's competence in mathematics and natural sciences, although this was not a majority voice of the parents. In addition to free tuition, these children were given myriad of activities which reflect the significance for developing both their spiritual and physical aspects. Empowerment felt by these students included learning moral education and Islamic teachings, which are not provided at other state elementary schools, but which are part of their family values. In addition, the parents are satisfied with SD Juara as a resource for them, as being the poor who live in a society where education has been commercialized. These parents are nonetheless able see their children benefit from schooling inclusive of moral values without the need for them to afford tuition fees.

Education, whatever religious group, state, or community possesses, should focus on developing two aspects of the child: spirituality and physics. The parents contended that the variety of activities which leads to building morality fits their life objective. Regarding this aspect, children in these Islamic schools are under guidance (mursyid) to perform regular prayers both in class and in the school mosque or outdoor. In addition to the prayers, they also participate in learning Islamic tradition and history and the Qur'an. The most significant result the students receive is that the moral teaching that has been added to science subjects made it possible for the students to mold their character and vision to become knowledgeable. 
Muslim schools were seen to have benefited from local initiatives and input from their communities. As seen in our observations and focus group discussions, these schools are also allowed to have a non-Muslim principal. This is a progressive step as it sometimes takes an outsider to readily perceive flaws and spur improvements in an organisation. This phenomenon is different from what these researchers see in Indonesia, where principals have the same faith as the majority of a school's students. Like SD Juara, Islamic schools in Sydney are inclusive to race, religion, culture, and social class. AICS and AMS are both open to enroll students from diverse backgrounds, while also empowering Muslim students with Islamic studies perspectives such as tafsîr, hadith, and variety of activities to further develop students' potential in all aspects. The students at these schools also stay longer in class (compared to other schools) in order to better learn subjects which teachers consider as difficult, a contributing factor in students excelling in state examinations.

The Islamic schools in Greater Sydney that we visited are developing several laboratories suited to various purposes such as physics, biology, mathematics, music, and sports laboratories. Because of this availability, students have greater chances to forge their ability and talent in sports, arts, and academics. Many students also recently won competitions locally. Some of them attained very high scores in the national examinations in New South Wales state. Methods for empowerment, as used by these Islamic schools, include extra-curricular activities, including scouting, sports, and optional extra hours of study for challenging courses. Students must attend required classes, but local schools can also add activities that exceed the minimum requirements. In visiting AICS and AMS, we saw that the combination of longer hours of study with physical and spiritual activities, plus the use of prayer facilities such as the school mosque and chaplaincy guidance, has boosted students' character, capability for studying, and opportunities for experiencing socialization.

The Islamic schools in Sydney that we visited have notable roles in empowering Muslim young people in a Christian-majority country. The schools serve as role models for teaching Muslim children to live in modernity and keep Islamic values at the same time. This empowerment serves as a method that helps marginalized or indigent people to become independent without neglecting their family heritage.

In Yogyakarta, SD Juara is affiliated with the Rumah Zakat Foundation, which collects zakat (religiously based charitable donations) from the public and distributes it to the poor and the indigent (Lessy, 2013). Students' fees at this school are waived and indeed, some refer to it as Sekolah Gratis. Located in an inner-city neighborhood of Yogyakarta, the motorists, drivers, and travelers easily notice the rented building. It occupies one entire block with a main building of two levels, and has some classrooms integrated into its community mosque. In Indonesia this was the first Sekolah Gratis, namely a school where students pay nothing. All students come from low-income families, and in order to be enrolled, they must pass a screening test which assesses whether their parents are poor. A qualifying family can send two children to the school at a time.

The teachers improve performance through improvisation in so-called thematic teaching styles. The school maintains physical and spiritual curricula in combination, as a balance between secular and spiritual teachings. In our focus group discussion, the anonymous participants agreed that the school helps them amid financial and economic difficulty by providing free education for indigent children. We saw how grateful the participants felt about this assistance. Even so, in an interview with one parent, we found her saying that she wants this school to add a priority for teaching science and mathematics. She wants her children to finish their schooling with high grades in those subjects so that they will be able to continue their education in public state-owned inexpensive secondary schools, which also offer good quality education. In order to empower children, the teaching can start from simple intentions, deeds, commitment, and work. We saw schools that began with only one class in a room divided between teaching and administration. And SD Juara has been able to help similarly disadvantaged children by waiving their tuition fees. 


\section{Conclusion}

Empowerment programs through education can be accomplished in many ways, and our research has investigated three schools offering programs and activities to emancipate minority and lowfamily-income students from lesser self-esteem and lesser independence, in order to integrate them into mainstream society and culture with a greater chance of economic success. The power of community building and a spirit of togetherness has shaped minority groups in Greater Sydney, New South Wales, to run their own schools for educating young Muslims amid observance of their own family culture, while expanding their horizons at the same time. These schools provide a powerful resource for unifying people from various ethnic backgrounds. These schools are open for students of any religion, ethnicity, culture, or political affiliation while at the same time providing the opportunity of values harmony for Muslim families. Despite having religious names connected with these schools, such as "Islamic" or "Muslim", their curricula have the independence to exist within a system of State or community support. They offer Qur'ân, târîkh, fiqh, hadîth, or tawhîd and other Islamic teachings to their students, so long as they also meet the minimum course requirements mandated by the State. We found that the students of these schools have benefited from learning science and mathematics, in preparation for higher education or future business acumen, while also gaining reinforcement of spirituality, for harmony with their family beliefs, in a time in which many other public schools do not offer both.

By contrast to the parents in our study, society's non-needy families can more easily afford the cost of elite schools, if they so choose. But the schools in our study are helping needy families and their children to overcome this hurdle by providing quality education without cost. It may also be noted that economic differences between neighborhoods sometimes leads to lack of self-esteem even among public school students. And the travel time and cost, for attending schools outside a family's neighborhood, make it difficult for poor children to attend distant institutions. As our research documented, these poor children often must spend some non-school time to assist in family businesses or care of siblings. Without the opportunity to attend schools such as the three cases studies in this paper, poor students would be less likely to have time for school related activities.

Traditionally, governments have acted as the decision makers for access to an educational system, but our study noted a trend for public schools to become more independent and selfgoverning. Meanwhile, many other schools stay lucrative because they accept children from the middle and upper classes without added assistance for those who are indigent. As competitiveness among such schools becomes more acute, many children citizens are left without sufficient access to good quality education. SD Juara is an example of an independent school that prepares students well, rivalling the results of other schools, while waiving tuition and fees. Their belief is that in order to create a good future for society, individuals or groups of people should invest today to empower low-income students with both academic and moral success. Our investigation noted that competitiveness in education is valuable but has often been beyond the reach of students who lack resources. Our study showed increasing attention to blending a fee-free and democratic environment with the technical and moral education desired by poor familes. In such settings, empowerment becomes multi-faceted.

\section{References}

Alavi, H.R. (2008). Nearness to God: A perspective on Islamic education. Religious Education, 103 (1), pp. 5-21.

Al-Noori Muslim School. (2017). School Magazine. Sydney, NSW: AMS

Al-Noori Muslim School. (2020). About Al-Noori Muslim School. Available at: http://alnoori.nsw.edu. au/about-al-noori-muslim-school/ [Accessed 10 January 2020].

Al-Syaukâni, M. (1417). Fath al-Qâdir. Beirut: Dâr al-Ma'ârif. 
Australian Islamic College of Sydney. (2017). Twenty Years Celebrating Excellence in Education. Sydney, NSW: AICS.

Bennetts, K., \& Bone, J. (2019). Adult leadership and the development of children's spirituality: Exploring Montessory's concept of the prepared environment. International Journal of Children's Spirituality, 24(4), pp. 356-370.

Cardinal, M.C. (2006). Religious education in Syria: Unity and difference. British Journal of Religious Education, 31(2), pp. 91-101.

Cheung, C.K. (2008). The teaching of moral education through media education. The Asia PacificEducation Researcher, 16(1), pp. 61-72.

Chowdhury, M. (2016). Emphasizing morals, values, ethics, and character education in science education and teaching science. The Malaysian Online Journal of Educational Science, 4(2), pp. 1-16.

Cipolle, S.B. (2010). Service Learning and Social Justice: Engaging Students in Social Change. New York: Rowman \& Littlefield.

Creswell, J.W. (2013). Qualitative Inquiry and Research Design: Choosing Among Five Approaches. Los Angeles, CA: Sage.

Davies, L. (1994). Beyond Authoritarian School Management: The Challenge for Transparency. Ticknall, Derbyshire: Education Now.

Ferguson, R.F. (2008). Helping students of color meet high standards. In M. Pollock (Ed.) Everyday Antiracism. New York: The New Press, pp. 77-81.

Foster, L.E. (1991). Australian Education: A Sociological Perspective. Sydney: Prentice-Hall.

Goldziher, I. (1981). Introduction to Islamic Theology and Law. New Jersey: Princeton University Press. Halstead, J.M. (2004). An Islamic concept of education. Comparative Education, 40(4), pp. 517-530.

Halstead, J.M. (2007). Islamic values: A distinctive framework for moral education? Journal of Moral Education, 36(3), pp. 283-296.

Hatton, E., Munns, G., \& Dent, J.N. (1996). Teaching children in poverty: Three Australian primary school responses. British Journal of Sociology of Education, 17(1), pp. 39-52.

Heydon, G. (1997). Teaching about Values: A New Approach. London: Cassels.

Hills, P.J. (1985). A Dictionary of Education. Boston: Routledge.

Hussain, A. (2008). Recent Western reflections on Islamic education. Religious Education, 103(5), pp. 579-585.

Kindervatter, S. (1979). Nonformal Education as an Empowering Process with Case Studies from Indonesia and Thailand. Unpublished Doctoral Thesis, University of Massachusetts, Amherst, Massachusetts, USA.

Lam, C.C. (1991). The Implementation of Curriculum Change in Moral Education in Secondary Schools in Hong Kong. Unpublished Doctoral Thesis, Institute of Education, University of London, UK.

Lee, J.A.B. (1996). The empowerment approach in social work practice. In F.J. Turner (Ed.) Social Work Treatment: Interlocking Theoretical Approaches. New York: The Free Press, pp. 218-249.

Lessy, Z. (2013). Philanthropic zakat for empowering Indonesia's poor: A Qualitative study of recipient experiences at Rumah Zakat. Unpublished Doctoral Thesis, Indiana University-Purdue University Indianapolis, Indiana, USA.

Lukens-Bull, R.A. (2000). Teaching morality: Javanese Islamic education in a globalizing era. Journal of Arabic and Islamic Studies, 3(2), pp. 26-47.

Maslen, G. (1992). School Ties: Private Schooling in Australia. Perth: Methuen Australia.

Neuman, W.L. (1997). Social Research Methods: Qualitative and Quantitative Approaches. Boston, MA: Allyn \& Bacon.

Nieto, S. (2008). Nice is not enough: Defining caring for students of color. In M. Pollock (Ed.) Everyday Antiracism. New York: The New Press, pp. 28-31.

Nilan, P. (2009). The 'spirit of education' in Indonesian Pesantren. British Journal of Sociology of Education, 30(2), pp. 219-232. 
Osman, Y. (2019). The significance in using role models to influence primary school children's moral development: Pilot study. Journal of Moral Education, 48(3), pp. 1-16.

Panjawi, F. (2012). Fazlur Rahman and the search for authentic Islamic education: A critical appreciation. Curriculum Inquiry, 42(1), pp. 33-55.

Payne, M. (2005). Modern Social Work Theory. New York: Palgrave Macmillan.

Prasilowati, S.L. (2000). An Analysis of Women's Education in Indonesia: Empowerment and Barriers. Unpublished Master's Thesis, Saint Mary's University, Halifax, NS, Canada.

Trethewey, A.R. (1990). The dimensions of inequality: A review. In P.J. Fensham (Ed.) Rights and Inequality in Australian Education. Melbourne: F.W. Cheshire, pp. 171-176

Yusuf, M. (2016). Religious Education in Indonesia: An Empirical Study of Religious Education Models in Islamic, Christian, and Hindu Affiliated Schools. Unpublished Doctoral Thesis, Radboud University, Nijmegen, the Netherlands.

Zulfikar, T. (2009). The making of Indonesian education. An overview on empowering Indonesian teachers. Journal of Indonesian Social Sciences and Humanities, 2, pp. 13-39. 
